\title{
Biological procedures to detect carcinogenic compounds in domestic wastewater
}

\author{
A. Malakahmad, T. S. Abd Manan \& N. Hilmin \\ Civil Engineering Department, \\ Universiti Teknologi PETRONAS, Malaysia
}

\begin{abstract}
Cancer is a leading cause of death worldwide and can be increased further to more than 13.1 million people per year by 2030. Cancer occurs due to the continuous exposure of carcinogenic compounds under certain concentrations. A carcinogen is an agent that can cause mutation, leading to cancer. Therefore, mutations are indications of the presence of carcinogenic compounds. The mutation effects in biological organisms are various. They are chromosomal aberrations, growth inhibition and teratogenic effects. These effects can only be detected through the application of biological approaches. This review gives descriptions on the biological detection and measurement of carcinogens in wastewater and water estuaries. The biological procedures such as the chromosomal aberration (CA), Comet assay, Micronucleus (MN) assay SOS chromotest and organic extraction of XAD with blue rayon is discussed. These bioassays played an important role in the detection of carcinogens from waterborne contaminants in the environment such as pesticides, industrial pollution and heavy metals. The evaluations are based on advantages and disadvantages, accuracy, speed and time factor of methods and experimental procedures. As cancer is often linked to DNA damage, these assays are also time and cost effective to estimate the carcinogenic potential of a compound. Thus, the concept of carcinogenic compounds detection and measurement in wastewater is of great attention due to their toxic and non-biodegradable nature.
\end{abstract}

Keywords: biological procedures, cancer, carcinogens, domestic wastewater, evaluations. 


\section{Introduction}

Mortality statistics estimate that cancer accounts for more deaths worldwide with an increasing number to more than 13.1 million people per year by 2030 [1]. Carcinogen is a potential compound that can cause cancer to humans based on certain concentrations or periods of time $[2,3]$. Water-borne carcinogens such as heavy metals ion, polycyclic aromatic hydrocarbons (PAHs), N-nitroso compounds, mycotoxins and Heterocyclic Amines (HCAs) are carcinogenic upon consumption [4-9].

Malaysia's 27 million people generate about six million tons or approximately 3 million cubic meters of sewage every year, at the cost of US\$ 0.3 billion for management, treatment, and to discharge the treated wastewater into the rivers $[10,11]$. Appropriate management of wastewater is of great concern at the wastewater treatment plants [12-15] as about 98\% of Malaysia's fresh water supply comes from surface water. Domestic wastewater is wastewater of residential areas origin. It is mainly from the substances of human metabolism and household activities. Over $90 \%$ of the carcinogenic loading comes from the domestic areas. Raw surface water becomes contaminated because of excessive and random discharge of wastewater directly from households to drains and finally into rivers with minimal or no treatment. These areas can achieve loading values greater than industrial zones with standard loading over discharging rate of more than $10^{9} \mathrm{~L} / \mathrm{d}$. The strong correlation between cancer and the presence of pollutants in wastewater have been proclaimed in previous studies [16-19]. The deterioration of water quality creates a hazard to the public health through poisoning or the spread of noncommunicable diseases like cancer [10, 11, 20, 21].

This review gives descriptions on the detection and measurement methods of carcinogens in domestic wastewaters through biological approaches. Therefore, the selection on the most appropriate method of detection and measurement can be made. The evaluations are based on advantages and disadvantages, accuracy, speed and time factor of methods and experimental procedures.

\section{History of genetic inheritance, mutation and cancer}

In the mid-nineteenth century, Mendel made a great discovery in genetics. His genetic investigations involved an experiment of approximately 30,000 pea plants of eight generations. The pea plants were bred and cross-bred at different characteristics. As for example, a tall plant bred to a short one will always produce tall offspring. The phenotypes of these bred pea plants will never blend to medium size. Moreover, the bred of these offspring produced three tall and one short offspring. These experiments showed that the characteristic of a plant depends on the inherited genes (genotype) and hence rejecting the Darwin's theory. Darwin's theory stated that organism's phenotype changed according to the adaptation on its environment and the characteristics of organisms were blended as they passed to the offspring producing new organism which explained the theory of evolution of humans [22]. 
Mutation can alter genomes randomly. Cancer cells often exhibit mutated or aberrantly structured chromosomes. Mutations in genes may produce cancer genes. These genes can be inherited. The genes carrier will survive. However, if the carrier married with another carrier, one of the children will suffer from cancer [22]. A mutagen is an agent or substance that able to cause different types of mutations. Mutagen can be biological, chemical or physical agents. Biological mutagen is commonly from viruses and metabolic activities of an organisms and organelles. Organelles are the components inside the cells of organisms. Chemical mutagens are from hazardous chemicals such as nitrous acid and hydrogen peroxide. Physical agents are from radiations from sun, cellular telephone, radioactive radon gas and electromagnetic waves from electric power lines [1-3, 22]. A carcinogen is an agent that induces abnormal pattern of growth in cells, directly leading to cancer [22]. Although not all of the mutations may cause cancer, it is undeniably that there is a strong correlation between the ability of a substance to induce mutations and its ability to induce cancer [1-3, 14-34].

\section{Detection methods}

Carcinogenic compounds can cause mutation. Therefore, mutations are the indications of the presence of carcinogenic compounds. The result of mutation is chromosomal aberrations and it can be detected through the applications of detection methods such as biological approaches.

\subsection{Anaphase/metaphase analyses and micronucleus analyses}

\subsubsection{Test background and history}

Chromosomal aberrations (CA) or abnormalities in chromosomes can be detected microscopically via Micronuclues Analyses and Anaphase/Metaphase analyses (A/M analyses) [23]. A/M analyses are commonly applied in the Allium cepa (onion) test. The common onion test $(2 \mathrm{n}=16)$ was first introduced by Levar in 1938 [24]. The chromosomes are large and easily observed compared to other plants. It makes a very convenient test system for estimating harmful effects of chemicals or environmental pollutants in wastewater. A/M analyses are based on Mitotic Index and Genotoxicity Index at the active mitosis site of a chosen plant; roots, stamen hair of a plant, pollen and shoot. Mitotic Index is based on the total number of cells in Prophase, Metaphase, Anaphase and Telophase over the total number of cells. Genotoxicity describes damage or a deleterious action on a cell's genetic material. Genotoxicity Index is based on the percentage of cells that contains chromosomal aberration. In the presence of genetic hazard pollutant, these aberrant cells can be observed in Anaphase and Metaphase stage [25].

A micronucleus (MN) is a small nucleus that is formed during mitosis or meiosis. It is a cytoplasmic body containing acentric chromosome or whole chromosome which was not carried to the opposite poles during the anaphase. Their formation results in the daughter cell lacking a part or all of a chromosome. These chromosome fragments or whole chromosomes normally 
develop nuclear membranes and form as small extra nucleus. Cell cultures are exposed to the test substances both with and without metabolic activation. Cytochalasin B is applied to block cytokinesis cell cultures for a period of time that is sufficient to allow chromosomal damage. Chromosomal damages can be observed from the formation of micronuclei in bi- or multinucleated interphase cells $[23,26]$.

\subsubsection{Applications}

There were numerous genotoxicity studies by previous scholars using the Allium cepa. The water samples were commonly from sewage effluent [27], industrial effluent [28], pharmaceutical effluent [29], industrial wastewater [30], surface water [31] as well as wastewater sludge [32]. Zeng et al. [33] studied on the pollution levels of three rivers passing through Fuzhou city. A literature survey by Grant and Owens [34] showed that the Crepis capillaries $(2 n=6)$ bioassay is an excellent plant bioassay for assessing chromosome damage induced by chemicals and environmental pollutants [34]. The genotoxicity of municipal landfill leachate was carried out by Sang and Li [35] via the Vicia faba bioassay. The results showed that leachate may pose a genotoxic risk to bio-organisms [35]. Table 1 summarized the chromosomal aberration assays of indicator plant species.

Table 1: The chromosomal aberration assays.

\begin{tabular}{|c|c|c|c|}
\hline Analyses & $\begin{array}{l}\text { Transducing } \\
\text { elements }\end{array}$ & Types of water sample & $\begin{array}{l}\text { Biomonitoring } \\
\text { protocols }\end{array}$ \\
\hline $\mathrm{A} / \mathrm{M}$ analyses & Allium cepa & $\begin{array}{l}\text { Sewage effluent/industrial } \\
\text { effluent/pharmaceutical } \\
\text { effluent/industrial } \\
\text { wastewater/surface water/ } \\
\text { wastewater sludge }\end{array}$ & $\begin{array}{l}\text { Mitotic Index and } \\
\text { percentage of root } \\
\text { length } \\
{[27-32]}\end{array}$ \\
\hline MN analyses & $\begin{array}{l}\text { Tradescantia } \\
\mathrm{sp}\end{array}$ & $\begin{array}{l}\text { Pollution levels of three rivers } \\
\text { in China/ }\end{array}$ & $\begin{array}{l}\text { MN frequencies } \\
\text { scoring procedure } \\
{[33]}\end{array}$ \\
\hline $\begin{array}{l}\mathrm{A} / \mathrm{M} \text { analyses } \\
\text { and } \mathrm{MN} \\
\text { analyses }\end{array}$ & $\begin{array}{l}\text { Crepis } \\
\text { capillaris }\end{array}$ & $\begin{array}{l}\text { Water contained insecticide at } \\
\text { different concentrations }\end{array}$ & $\begin{array}{l}\text { MN frequencies } \\
\text { scoring procedure } \\
\text { [34] }\end{array}$ \\
\hline $\begin{array}{l}\mathrm{A} / \mathrm{M} \text { analyses } \\
\text { and } \mathrm{MN} \\
\text { analyses }\end{array}$ & Vicia faba & Municipal landfill leachates & $\begin{array}{l}\text { Mitotic Index and } \\
\text { MN frequencies } \\
\text { scoring procedure } \\
{[35]}\end{array}$ \\
\hline
\end{tabular}

\subsubsection{Evaluation}

Analyses and Anaphase/Metaphase Analyses are highly in demand due to the simple preparation method as well as the ease in availability of materials and equipments. However, the evaluation of CAs is time consuming and facilitated by the use of indicator plant species that have a small number of large chromosomes include Allium cepa Tradescantia sp., Crepis capillaris and Vicia faba. 


\subsection{Ames test}

\subsubsection{Test background and history}

Ames test was introduced in 1975, by Bruce Ames a bacterial geneticist. It involves an experiment of growing bacteria on agar plates and comparing natural mutation rates to mutation rates of bacteria exposed to potentially mutagenic compounds or samples [36]. In this test, an extract of rat liver called S-9 mix and containing of microsomal enzymes and cofactors, is often added to the bacteriological medium. The medium contains genetically modified Salmonella typhimurium strains. The presence of mutations in the histidine genes, causing defects in a metabolic pathway leading to the production of histidine, allows positive selection of histidine revertants on minimal agar plates lacking histidine. Only mutants that able to restore of this function occurred are able to form colonies on such plates. Usually the plates containing the tested compound and tester bacteria are incubated for 48 hours and bacterial colonies are counted [36].

\subsubsection{Application}

The mutagenic and antimutagenic activities of forty-two synthetic flavones were evaluated via the Ames test by Beudot et al. [38]. The tested flavones included twenty-three 3-nitroflavones, eighteen 3-aminoflavones and 3-chloroflavone. It was found that the mutagenicity of the 3-aminoflavones required the presence of the metabolic activation. Meanwhile, the 3-amino derivatives were more mutagenic than the 3-nitro counterparts [38]. Total and fractionated organic extracts from industrial effluents and Labe river water were tested for mutagenicity effect using the Ames test with TA98 strain and its YG derivatives (YG1021, YG1024 and YG1041) and cytogenetic analysis with human peripheral lymphocytes in vitro. The mutagenicity effect was found to be dosedependent. The mutagenicity effect was also detected in polar acidic and polar basic fractions in fractionated samples. The cytogenetic effect in human peripheral lymphocytes in vitro was not significant. Thus, in this research the increase in chromosomal aberrations was not clearly dose-dependent and may reflect more on the clastogenic effects [39].

\subsubsection{Evaluation}

The Ames test is excellent for testing mutagenic activity of defined chemicals under laboratory conditions. However, the limitations of the assay are the survival of tester strains which is sensitive to water samples containing high salt concentrations. In addition, the sensitivity of the test may be too low for the detection of low amounts of mutagens in environmental samples. The tester strain also is potentially pathogenic bacterium that can cause diarrhoea and food poisoning.

\subsection{Salmonella assay}

\subsubsection{Test background and history}

The Salmonella assay is widely used for genotoxicity detection in water samples. It is based on the detection of histidine-independent revertants in selected strains 
after exposure to mutagens with or without activation enzymes. Some researchers combined the salmonella assay with other biological tests such as the Micronucleus $(\mathrm{MN})$ test and $\mathrm{A} / \mathrm{M}$ Analyses for a good correlation and interpretation of results $[40,41]$.

\subsubsection{Application}

Lemos et al. [42] studied genotoxic potential of a river basin under impact of agricultural, urban and industrial activities influence of climatic variation. The Salmonella assay different strains were performed. Upper river basin shows a low pollution mainly from small farm. Other result showed high concentration mutagenic responses at Sinos river in the middle and lower reaches influenced by large discharge from domestic sewers and industries [42]. The mutagenicity of aluminium oxide nanomaterials (NMs) $\left(\mathrm{Al}_{2} \mathrm{O}_{3}-30 \mathrm{~nm}\right.$ and $\left.\mathrm{Al}_{2} \mathrm{O}_{3}-40 \mathrm{~nm}\right)$ was carried out using the Ames test by Balasubramanyam et al. [43]. The bacterial strains used was Salmonella typhimurium TA100, TA1535, TA98, TA97a and TA102, in the presence and absence of the S9 mixture. However, no significant changes were found in the number of revertant colonies (with or without S9 mixture) at different concentrations of $\mathrm{Al}_{2} \mathrm{O}_{3}-30 \mathrm{~nm}$ and $\mathrm{Al}_{2} \mathrm{O}_{3}-40 \mathrm{~nm}$ tested compared to the $\mathrm{Al}_{2} \mathrm{O}_{3}$-bulk and control. The findings suggested that $\mathrm{Al}_{2} \mathrm{O}_{3} \mathrm{NMs}$ were invalid of any size and concentration dependent mutagenicity compared to the $\mathrm{Al}_{2} \mathrm{O}_{3}$-bulk and control. It shows that Salmonella sp. might probably resistant to these compound materials [43].

\subsubsection{Evaluation}

Salmonella sp. has resistance to certain compound materials. Thus, Salmonella assay is not prominent for certain compound materials and it is yet to be ascertained.

\subsection{SOS chromotest}

\subsubsection{Test background and history}

The SOS chromotest is as an alternative to the conventional Ames test. SOS chromotest (on Escherichia coli PQ37) is measured by determination of the betagalactosidase enzyme activity.

\subsubsection{Application}

The microplate version of the SOS chromotest was developed as a sensitive screening of genotoxins in water samples [44] such as heterocyclic amines [45]. This test version provides a qualitative (the observable changes in color gradient) and quantitative measurements (spectrophotometry with calculation of commonly accepted metrics unit) for the tested samples [49]. Jolibois and Guerbet [46] evaluated water samples via the combination of the SOS chromotest (on Escherichia coli PQ37) and the Salmonella fluctuation test on Salmonella typhimurium different strains with or without metabolic activation. The water samples were taken from the Rouen University Hospital, the Rouen wastewater (hospital effluents mixed with urban and industrial effluents), the wastewater treatment plant (hospital, industrial and domestic), and the Grand 
Couronne wastewater treatment plant (domestic wastewater). The results showed that samples collected in domestic wastewater were slightly genotoxic as the samples collected in mixed wastewater [46].

\subsubsection{Evaluation}

The accuracy and sensitivity of this biological assay is comparable to Ames test. It is less time consuming and widely used for genotoxicity monitoring in water samples. However, Escherichia coli PQ37 is one of the strains of pathogenic bacteria. Therefore, the SOS Chromotest needs special safety culture bacteria laboratory to avoid dangerous effect when dealing with bacteria.

\subsection{Comet assay}

\subsubsection{Test background and history}

The Comet Assay is also called as Single Cell Gel Electrophoresis (SCGE). This technique was developed by Swedish researchers, Ostling and Johansson in 1984 [47]. It is a sensitive and rapid technique for quantifying and analyzing DNA damage in individual cells. It has been applied in both animal eukaryotes and plant cells studies. On the contrary, it also has been used to monitor DNA repair in cancer research such as the evaluation of genotoxicity and effectiveness of chemoprevention in living cells [47]. Singh et al. [48] later modified this technique in 1988. It is called the Alkaline Comet Assay. The resulting image obtained resembles a "comet" with a distinct head and tail. The head is composed of intact DNA, while the tail consists of damaged or broken pieces of DNA [48].

\subsubsection{Application}

Lemos et al. [49] conducted comet assay in Tilapia rendalli fish of lake Igapo II, Brazil. Results demonstrated that samples had a significantly genotoxicity greater number of comets class 2 (medium damage) and class 3 (extensive damage) [49]. Rocha et al. [50] conducted in vitro comet assay with fish cell and in situ MN assay using erythrocytes from tilapia (Oreochromis niloticus) in Tiete River, Brazil. Results from in vitro comet assay documented two sites near Spring and Billings reservoirs show strong genotoxicity. For in situ MN assay, the fish collected from Billings reservoirs revealed highest MN frequencies [50]. Summak et al. [51] conducted in vivo MN test in Nile tilapias (Oreochromis niloticus) blood erythrocytes along the Nilufer Stream, Turkey. The results indicated the stream was contaminated with potential genotoxic chemicals related with industrial, agricultural and domestic activities [51].

\subsubsection{Evaluation}

Theoretically, the comet assay can be used for all animal cells. Unfortunately, sometime consistent data are not achieved. Human lymphocytes are the most reliable cells used for the comet assay. However, not all the damage to cells and organs are detectable using lymphocytes. In addition, lymphocytes are not reliable to study repair system since they are very slow to repair their damage. The comet assay is not able to detect small DNA fragments (smaller than $50 \mathrm{~kb}$ ). 


\subsection{Organic extraction with XAD and blue rayon}

\subsubsection{Test background and history}

Organic extraction in column using XAD resins and blue rayon is regularly applied method for genotoxic compounds in rivers contaminated with domestic sewage due to its capability to adsorb a class of mutagenic compounds such as polycyclic aromatic hydrocarbons (PAHs) and arylamines. Organic extraction in column using XAD resin had shown positive results in literature when those extracts were tested and compared to the water sample using Salmonella assay $[52,53]$.

\subsubsection{Application}

Kummrow et al. [52] analyzed a river under the influence of discharges of an azo-dye processing plant and a water reservoir contaminated with untreated domestic sewage by performing organic extraction in columns packed with XAD4 resin and with blue rayon. Results indicated that mutagenicity river water was much higher for both blue rayon and XAD4 extracts when compared to the water from the reservoir using Salmonella assay [52]. Oda et al. [53] conducted experiment to understand the basis of human cytochrome P450 (CYP) and Nacetyltransferases (NATs) in genotoxic activation of PBTA-4, PBTA-6, PBTA7, and PBTA-8 and identified them as major mutagens in blue cotton/rayonadsorbed substances collected at sites municipal water treatment plants treating domestic wastewater and effluents from textile dyeing factories in several rivers in Japan [53].

\subsubsection{Evaluation}

The hanging technique using blue rayon specifically adsorbs mutagens with multicyclic planar structures. It has advantages over most conventional methods of not having to bring large volumes of water back to the laboratory for extraction of organic materials. Blue cotton/rayon-adsorbed using blue rayon or blue cotton as an adsorbent is appropriate and easily applied for genotoxicity detection in water samples affected by domestic waste. It can collect large quantities of unidentified chemicals. However, it has a disadvantage of not allowing quantitative analysis.

\section{Conclusions}

The presence of carcinogens has been reported in domestic wastewater. Poor performance of sewage treatment plants cause release of these carcinogenic compounds to the surrounding watercourses. This review presented current studies on the analysis of carcinogens in wastewater through biological approaches. The biological approaches described that chromosomal aberration (CA) assays is faster, scientifically reliable and relatively low in cost compared to Comet assay, MN analyses, SOS chromotest and organic extraction with XAD and blue rayon. As detection tools, the possession, operations and maintenances cost of these methods is the main drawback for their wide applications. 


\section{Acknowledgements}

The authors gratefully acknowledge the financial support from the Universiti Teknologi PETRONAS and the Ministry of Higher Education (MOHE) Malaysia, under Exploratory Research Grant Scheme (ERGS) no. 15-8200-136.

\section{References}

[1] World Health Organization (WHO), Fact Sheet: Cancer. Online. http://www.who.int/mediacentre/factsheets/fs297/en/

[2] Weinberg, R.A., The Biology of Cancer, Garland Science, Taylor \& Francis Group: New York, United States of America and United Kingdom, pp. 1-50, 2007.

[3] Kitchin, K.T., Carcinogenicity: Testing, Predicting and Interpreting Chemical Effects, Marcel Dekker, Inc; New York, United States of America, pp. 1-80, 1999.

[4] Wescoat, J.L. \& White, G.F., Water for Life: Water Management and Environmental Policy, The Press Syndicate of the University of Cambridge: United Kingdom, pp. 140-145, 2003.

[5] White, P.A. \& Rasmussen, J.B., The genotoxic hazards of domestic wastes in surface waters, Mutation Research, 410, pp. 223-236, 1998.

[6] Saxena, P.B., Chemistry of Polycyclic and Heterocyclic Compounds, Discovery Publishing House: India, pp. 20-45, 2007.

[7] Luch, A. The Carcinogenic Effects of Polycyclic Aromatic Hydrocarbon, Imperial College Press: London, pp. 1-50, 2004.

[8] Sugimura, T., Wakabayashi, K., Nakagama, H., \& Nagao, M., Heterocyclic amines: mutagens/carcinogens produced during cooking of meat and fish, Cancer Sciences, 95, 290-299, 2004.

[9] Clayson, D.B., Toxicological Carcinogenesis Lewis Publishers: Florida, United States of America, pp. 1-80, 2000.

[10] Ngadimin, N.W., Factors Influencing to the Selection of Sewage Treatment Plant, Faculty of Civil Engineering, Universiti Teknologi Malaysia: Malaysia, 2010.

[11] Kadir, M.D.A. \& Velayutham, S., The management of municipal wastewater sludge in Malaysia, Symp. on Sludge Management, Universiti Teknologi Malaysia: Skudai, Malaysia, 1999.

[12] LaGrega, M.D., Buckingham, P.L. \& Evans, J.C., Hazardous Waste Management, McGraw-Hill Companies: New York, United States of America, 2001.

[13] Laugesen, C.H. \& Fryd, O., Sustainable Wastewater management in Developing Countries: New Paradigm and Case Studies from the Field, American Society of Civil Engineers: United States of America, 2009.

[14] Mara, D., Domestic Wastewater Treatment in Developing Countries, Earthscan: United Kingdom, 2004. 
[15] Arceivala S.J. \& Asolekar S.R., Wastewater Treatment for Pollution Control and Reuse, Tata-McGraw-Hill Publishing company: New Delhi, India, 2007.

[16] Bhunia, P.K., Optimal Design and Operation of Wastewater Treatment Plants. Civil Engineering Department, University of California: Los Angeles, United States of America, 1986.

[17] Sadiq, R., Rajani, B. \& Kleiner, Y., Risk analysis for water quality deterioration in distribution, evaluation and control of water loss in urban water networks, NRCC: Spain, 47067, pp. 1-26, 2004.

[18] Thakur, J.S., Rao, B.T., Rajwanshi, A., Parwana, H.K. \& Kumar, R. Epidemiological study of high cancer among rural agricultural community of Punjab in Northern India, International Journal of Environmental Research and Public Health, 5, pp. 399-407, 2008.

[19] Koivusalo, M., Jaakkola, J.J.K., Varliainen, T., Hakulinen, T., Karialainen, S., Pukkala, E. \& Tuomisto, J., Drinking water mutagenicity and gastrointestinal and urinary tract cancers: An ecological study in Finland, American Journal of Public Health, 84, pp. 1223-1228, 1994.

[20] Kraybill, H.F., Carcinogenesis induced by trace contaminants in potable water, A Symposium on Carcinogens held by Blue Cross and Blue Shield of Greater New York, New York Academy of Medicine: New York, 54, pp. 413-427, 1978.

[21] Zalina, A., Nik Rosmawati, N.H. \& Zaliha, I., Factors associated with preferences for safe drinking water among outpatients at Hospital Universiti Sains Malaysia (HUSM), Kelantan, Malaysia, Health and the Environment Journal, 4(1), pp. 31-41, 2013.

[22] Campbell N.A. and Reece J.B. 2009. The chemistry of life (Chapter 1). The cell (Chapter 2). Genetics (Chapter 3). Mechanisms of evolution (Chapter 4). The evolutionary history (Chapter 5). Animal form and function (Chapter 7). Campbell Biology. Pearson Education Incorporation: Lake Ave, Glenview Illinois, United States of America, pp. 1-800, 2009.

[23] Maluszynska, J. \& Juchimiuk. J., Plant genotoxicity: A molecular cytogenetic approach in plant bioassays, Journal of Plant Genotoxicity, 56, pp. 177-184, 2005.

[24] Fiskesjö, G., The allium test in wastewater monitoring, Environmental Toxicology and Water Quality, 8(3), pp. 291-298, 1993.

[25] Fiskesjö, G., The Allium test as a standard in environmental monitoring, Hereditas, 102, pp. 99-112, 1985.

[26] Fenech, M., The Micronuclues assay determination of chromosomal level DNA damage, Methods Molecular Biology, 410, pp. 185-216, 2008.

[27] Ukaegbu, M.C. \& Odeigah, P.G.C., The genotoxic effect of sewage effluent on Allium cepa, Report and Opinion, 1(6), pp. 36-41, 2009.

[28] Samuel, O.S., Osuala, F.I. \& Odeigah, P.G.C., Cytogenotoxicity Evaluation of Two Industrial Effluents using Allium cepa Assay, African Journal of Environmental Science and Technology, 41(1), pp. 21-27, 2009. 
[29] Abu, N.E. \& Mba, K.C., Mutagenicity testing of pharmaceutical effluents on Allium cepa root tips meristems. Journal of Toxicology and Environmental Health Sciences, 3(2), pp. 44-51, 2011.

[30] El-Shahaby, O.A., Abdel Migid, H.M., Soliman, M.I. \& Mashaly, I.A., Genotoxicity screening of industrial wastewater using the Allium cepa chromosome aberration assay, Pakistan Journal of Biological Sciences, 6(1), pp. 23-28, 2003.

[31] Monte Egato, L.C., Medeiros, M.D.G., Medeiros, S.R.B.D. \& AgnezLima, L.F., Cytotoxic and genotoxic potential of surface water from the Pitimbu river, northeastern/RN Brazil, Genetics and Molecular Biology, 30(2), pp. 435-441, 2007.

[32] Rank, J. \& Nielsen, M.H., Genotoxicity testing of wastewater sludge using the Allium cepa anaphase-telophase chromosome aberration assay, Mutation Research/Genetic Toxicology and Environmental Mutagenesis, 418(2-3), pp. 113-119, 1998.

[33] Zeng, D. M., Li, Y. \& Lin, Q.Q., Pollution monitoring of three rivers passing through Fuzhou City, People's Republic of China, Mutation Research, 426, pp. 159-161, 1999.

[34] Grant, W.F. \& Owens, E.T., Chromosome aberration assays in Crepis for the study of environmental mutagens, Mutation Research/Reviews in Mutation Research, 410, pp. 291-307, 1998.

[35] Sang, N. \& Li, G., Genotoxicity of municipal landfill leachate on root tips of Vicia faba, Mutation Research, 560, pp. 159-165, 2004.

[36] Levski, J. M. \& Singer, R. H., Gene expression and the myth of the average cell, Trends in Cell Biology, 13, pp. 4-6, 2003.

[37] Mortelmans, K. \& Zeiger, E., The Ames Salmonella/Microsome mutagenicity assay, Mutation Research, 455, pp. 29-60, 2000.

[38] Beudot, C., De Méo, M.P., Dauzonne, D., Elias, R., Laget, M., Guiraud, H., Balansard, G. \& Duménil, G., Evaluation of the mutagenicity and antimutagenicity of forty-two 3-substituted flavones in the Ames test, Mutation Research, 417, 141-153, 1998.

[39] Černá, M., Pastorková, A., Šmíd, J., Bavorová, H., Očadlíkoví, D., Rössner P. \& Zavadil. J., Genotoxicity of industrial effluents, river waters and their fractions using the Ames test and in vitro cytogenetic assay. Toxicology Letters, 88:191-197, 1996.

[40] Rehana, Z., Malik, A. \& Ahmad, M., Genotoxicity of the Ganges water at Narora (U.P.), India, Mutation Research, 367, 187-193, 1996.

[41] Takamura-Enya, T., Watanabe, T., Tada, A., Hirayama, T., Nukaya, H., Sugimura, T. \& Wakabayashi, K., Identification of a new mutagenic polychlorinated biphenyl derivative in the Waka river, Wakayama, Japan, showing activation of an aryl hydrocarbon receptor-dependent transcription, Chemical Research Toxicology, 15, pp. 419-425, 2002.

[42] Lemos, A.T., Rosa, D.P., Rocha, J.A.V. \& Vargas, V.M.F., Mutagenicity assessment in a river basin influenced by agricultural, urban and industrial sources, Ecotoxicology and Environmental, 72, pp. 2058-2065, 2009. 
[43] Balasubramanyam, A., Sailaja, N., Mahboob, M., Rahman, M.F., Saber, M., Hussain \& Grover, P., In vitro mutagenicity assessment of aluminium oxide nanomaterials using the Salmonella/Microsome Assay, Toxicology in Vitro, 24, pp. 1871-1876, 2010.

[44] White, P.A., Rasmussen, J.B. \& Blaise, C., A semi-automated, microplate version of the SOS Chromotest for the analysis of complex environmental extracts, Mutation Research, 360, 51-74, 1996.

[45] Ohe, T., Quantification of mutagenic/carcinogenic heterocyclic amines, MeIQx, Trp-P-1, Trp-P-2 and PhIP, contributing highly to genotoxicity of river water, Mutation Research, 393, 73-79, 1997.

[46] Jolibois, B. \& Guerbet, M., Evaluation of industrial, hospital and domestic wastewater genotoxicity with the Salmonella fluctuation test and the SOS chromotest, Mutation Research, 565, pp. 151-162, 2005.

[47] Ostling, O. \& Johansson, K.J., Microelectrophoretic study of radiationinduced DNA damages in individual mammalian cells, Biochemistry \& Biophysics Research Community, 123, pp. 291-298, 1984.

[48] Singh, N.P., McCoy, M.T., Tice, R.R. \& Schneider, E.L., A simple technique for quantitation of low levels of DNA damage in individual cells, Experiment Cell Research, 175, pp. 184-191, 1988.

[49] Lemos, N.G., Dias, A.L., Silva-Souza, A.T. \& Mantovani, M.S., Evaluation of environmental waters using the comet assay in Tilapia rendalli, Environmental Toxicology and Pharmacology, 19, 197-201, 2005.

[50] Rocha, P.S., Luvizotto, G.L., Kosmehl, T., Bottcher, M., Storch, V., Braunbeck, T. \& Hollert, H., Sediment genotoxicity in the Tiete River (Sao Paulo, Brazil): In vitro comet assay versus in situ micronucleus assay studies, Ecotoxicology and Environmental Safety, 72, pp. 1842-1848, 2009.

[51] Summak, S., Aydemir, N.C., Vatan, O., Yılmaz, D., Zorlu, T. \& Bilaloglu, R., Evaluation of genotoxicity from Nilufer Stream (Bursa/Turkey) water using piscine micronucleus test, Food and Chemical Toxicology, 48, pp. 2443-2447, 2010.

[52] Kummrow, F., Rech, C.M., Coimbrão, C.A., Roubicek, D.A. \& Umbuzeiro, G.A., Comparison of the mutagenic activity of XAD4 and blue rayon extracts of surface water and related drinking water samples, Mutation Research, 541, pp. 103-113, 2003.

[53] Oda, Y., Watanabe, T., Taro, Y., Nukaya, H. \& Wakabayashi K., Genotoxic activation of 2-phenylbenzotriazole-type compounds by human cytochrome P4501A1 and N-acetyltransferase expressed in Salmonella typhimurium umu strains, Mutation Research, 654, pp. 52-57, 2008. 